\title{
TEACHING ENGLISH TO YOUNG LEARNERS: LEARNING MATERIALS
}

\author{
B. Yuniar Diyanti \\ Yogyakarta State University
}

\begin{abstract}
Materials are important resources for teachers in assisting pupils to learn English. In broader view, materials can be defined as anything which is used specifically with the intention of increasing pupil's knowledge and experience of the language. Therefore materials may include textbooks (coursebooks), workbooks, story books, videos, cassettes, pictures, brochures, menus, interactive CDs, or other real-life artifacts, (Moon, 2003: 86). In choosing and selecting materials for the teaching practices, we need to have several considerations like whether we have to create the materials ourselves, how we can select appropriate materials for our pupils, how we can adapt the materials in assisting our learners in learning, and what the benefits are of either adapting or creating our own learning materials. The article then aims at discussing these considerations in choosing, selecting, or creating learning materials in the teaching of English for your learners.
\end{abstract}

Key words: Learning materials, selecting, choosing, and adapting materials

Nowadays, there are wide varieties of readily-available materials in the stores like course books from all publishers and textbook writers, or picture cards and story books, or interactive language activity CDs. Teachers can always select and choose one or more of those materials and use them in their teaching practices. Some questions like whether the materials are suitable for the pupils' age level, interest, and cognitive development, whether we have to create our own materials or simply buy them, or whether we can afford the money and the time producing or buying the materials might arise. Additionally, there may also be questions like whether teachers should only use the materials from the course books or how many supplementary materials teachers can use in class to support the course book materials. 


\section{A. Creating materials}

Moon (2003: 86) states that teachers' conditions vary in at least three ways. Some teachers have access to a range of course books and supplementary materials to choose, some have to follow a prescribed textbook, and some others do not use or do not have course books and produce their own materials. Yet, most of them have access to at least one course book. However, textbooks are made for general students and not specially designed to meet certain needs, while in creating own materials, teachers face some problems like the limitation of times, the lack of money, the problem in expertise and experience, limited self confidence, and the limited source and reference materials. Therefore, Moon (2003) also suggests several solutions to these common teachers' problems;

1. Problem 1: lack of time in designing the materials

Involve your students in cutting, gluing, and in doing other practical jobs. They can also make the illustration for teachers. This will be beneficial because students would really feel that they are really involved in designing their learning materials and they will also get the chance to use the TL. Furthermore teachers will have the benefits of having more materials produced.

2. Problem 2: lack of cost involved

Working together with other teachers from the same school or even from the same district would overcome this problem. Some cards or worksheets can be reused by laminating them so they will last longer. Students can write the answers to the questions in their own books.

3. Problem 3: lack of skills and expertise

If teachers have taught several years, then they will have enough experience and expertise from their teaching practice. The key is to be confidence and to have the willingness to try to design the materials. Those who have very little experience can always adapt materials and activities from the course book and modify them a little.

4. Problem 4: lack of course book/reference books from which to get ideas

Getting together with other teachers from the same school or other teachers from other schools locally in order to gain ideas is always a good one to try. Joining teachers group to develop professionalism is another option. Taking out subscription of a teacher's magazine then share the cost with other teachers would also be beneficial. Last but not least, teachers can always get so many useful activities from the internet by browsing several sites to get pictures or 
examples of lesson plan. Two of the sites which provide very resourceful pictures, flashcards, and stickers are the www.mes-english.com and the www.bogglesworldesl.com. The pictures are theme-based arranged, and therefore easy for teachers to choose the pictures which suit their needs. Here are some samples of the pictures that can be downloaded freely from www.mesenglish.com:
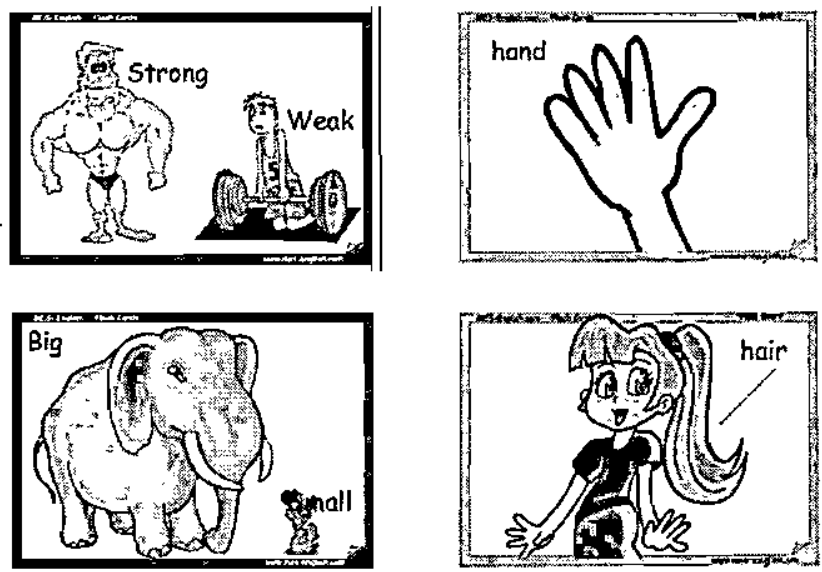

\section{Figure 1: Flashcards}

Besides the two sites mentioned previously above, teachers can also access www.teachchildrenesl.com for some valuable lesson plans and freely downloaded materials and worksheets. The www.teachchildrenesl.com particularly provides teachers with materials that can be chosen to suit the students' needs and level of education. The materials range from vocabulary games like crosswords or word search to reading and writing practices. It is worth the while to spend a little time to browse and download some materials from this site.

5. Problem 5: limited self-confidence

Doing all the designing and adapting the materials regularly will gradually develop teachers confidence in creating their own materials. Teachers can also ask peer

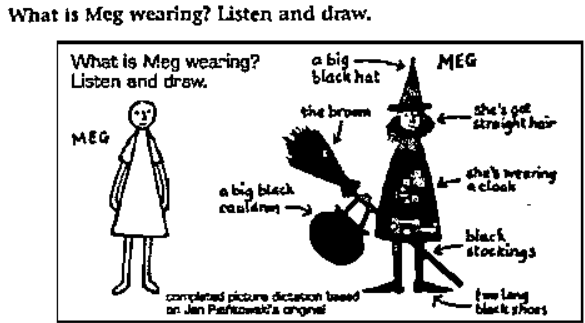

Fig. 29 Picture dictation workshect 
teachers or superior teachers to evaluate their design and learn from the feedbacks.

The figure below is one of the examples of teachers-produced worksheet for listening activity (copied from figure 29 in Brewster et.al., 2003)

\section{B. Selecting Course book Materials}

Spratt et.al (2005: 110) define course book materials as all the materials in a course book package that we use in the classroom to present and practice language, and to develop learner's language skills. A course book package, they add, usually includes a student's book, a teacher's book, and audio and/or video recordings. Often there is also a workbook or an activity book included in the package. In selecting course book materials, Spratt et.al (2005) suggest several questions that teachers can use as guidelines;

a. Is the material visually attractive? Is it visually clear (using different colors, different fonts, headings, etc.)? Does the visual material help pupils to understand contexts and meaning?

b. Is it well-organized? Can you and your students follow the logic of the material and find your way around the page or the unit quickly and easily?

c. Is it culturaily appropriate? Will the context(s) be familiar to learners?

d. Is it suitable for your leamers' age and their needs and interests?

e. Will the topic be motivating to suit age, gender, experience and personal interests of your learners?

f. Is it at the right level? Does it provide a clear enough context and/or explanations for the learners to understand new language?

g. Does it give learners enough opportunities to use the language?

When all or most of the answers are $N O$, Spratt et.al (2005: 110) suggest to replace the course book materials with other materials which have the same focus/aim from another book or resource, from the websites or supplementary materials. But if teachers cannot replace the course book with other books, teachers can always adapt the material, that is, to change it in some ways to make it suitable for the pupils. Spratt et.al. (2005) give some ideas of how teachers can adapt materials to suit to particular teaching situation: 


\section{Table 1: Strategies, Problems, and Solutions in Adapting Materials}

\begin{tabular}{|c|c|c|}
\hline Strategies & Problems & Possible Solutions \\
\hline $\begin{array}{l}\text { extending } \\
\text { material }\end{array}$ & $\begin{array}{l}\text { - the task or exercise is too short } \\
\text { - the learners need more practice }\end{array}$ & $\begin{array}{l}\text { write extra items, following the } \\
\text { same pattern }\end{array}$ \\
\hline shortening & - the task or exercise is too long & $\begin{array}{l}\text { use as much as you need, but do } \\
\text { not feel you have to use all }\end{array}$ \\
\hline & $\begin{array}{l}\text { - the learner s don't need so } \\
\text { much practice }\end{array}$ & $\begin{array}{l}\text { - give different parts of the text or } \\
\text { task to different learners }\end{array}$ \\
\hline $\begin{array}{l}\text { changing the } \\
\text { form of the } \\
\text { tasks }\end{array}$ & $\begin{array}{l}\text { - the task doesn't suit the leamers' } \\
\text { learning style } \\
\text { - you want a change of pace } \\
\text { - the course book often repeats } \\
\text { the same kind of task }\end{array}$ & $\begin{array}{l}\text { change the interaction pattern, } \\
\text { e.g. use a matching task as a } \\
\text { mingling activity (i.e. one in } \\
\text { which leamers move around the } \\
\text { class to find partners) }\end{array}$ \\
\hline $\begin{array}{l}\text { changing the } \\
\text { level of the } \\
\text { material }\end{array}$ & $\begin{array}{l}\text { - the texts or tasks are too } \\
\text { easy or too difficult }\end{array}$ & $\begin{array}{l}\text { make material more challenging, e.g. } \\
\text { learners try to answer comprehension } \\
\text { questions before reading }\end{array}$ \\
\hline & & $\begin{array}{l}\text { make material less challenging, e.g. } \\
\text { break up a long text, into shorter sections }\end{array}$ \\
\hline $\begin{array}{l}\text { reordering } \\
\text { material }\end{array}$ & $\begin{array}{l}\text { the activities in the units in } \\
\text { the book always follow the same } \\
\text { sequence } \\
\text { the learners need to leam or } \\
\text { practice things in a different order }\end{array}$ & $\begin{array}{l}\text { change the order of the material, e.g. } \\
\text { ask learners to cover up a page or part } \\
\text { of page, so that they focus on what you } \\
\text { want them to do first }\end{array}$ \\
\hline $\begin{array}{l}\text { making use } \\
\text { of all the } \\
\text { resources }\end{array}$ & $\begin{array}{l}\text { - there is not enough practice } \\
\text { material in a particular unit }\end{array}$ & $\begin{array}{l}\text { use extra material from the book: } \\
\text { grammar summaries, word lists, } \\
\text { list of verbs and expressions, etc. }\end{array}$ \\
\hline in the book & $\begin{array}{l}\text { - the leamers need to } \\
\text { revise particular items } \\
\text { you want to preview } \\
\text { material in a future unit }\end{array}$ & $\begin{array}{l}\text { give whole-book tasks, e.g } \\
\text { searching through the book for } \\
\text { texts, pictures, language examples }\end{array}$ \\
\hline
\end{tabular}


When adapting the materials, we need also to consider whether or not the leaving out of one or two of the units create confusion on the students' part, since course book is sometimes the main resource of materials. Make sure our pupils are aware of what they have to do in the lesson. However, when materials need to be more personalized, Spratt et. al. suggest teachers to provide additional activities for the materials, as shown in the following table:

Table 2: Teachers' strategy in personalizing materials

\begin{tabular}{|ll|}
\hline \multicolumn{1}{|c|}{ Coursebook provides: } & Teacher can provide additional: \\
\hline situation/context & Warmer \\
Pictures & Instructions \\
dialogues (conversations between two & role-play \\
people) and texts & \\
tasks and exercises & homework tasks \\
\hline
\end{tabular}

Adapted from Spratt et.al. (2005).

When teachers plan to reorder the lesson, make sure that the organization of the coursebook would allow that to happen, i.e. the lesson does not depend on the previous lesson. Last but not least, teachers can always make the material more interesting by using mime, gestures, and realia when presenting the materials.

\section{Selecting and Using Supplementary Materials}

Spratt et.al. (2005) define supplementary materials as books and other materials we can use in addition to the course book. Supplementary materials include skill development materials (grammar, vocabulary and phonology practice materials), collection of communicative activities and teachers' resource materials, authentic sources (newspaper or magazine articles, video, etc), and free downloaded materials from the internet.

1. Skill development materials (grammar, vocabulary and phonology practice materials). Some materials that teachers can use to maintain their language proficiency and deepen their insight knowledge on the practice of TEYLare:

a. How to Teach Pronunciation, by Gerald Kelly, published 2000 by Pearson Education Ltd. This book is equipped by an audio $C D$ that teachers can use to help them improve their pronunciation skill. 
b. Practical English Language Teaching: Young Learners, by Caroline T. Linse, published 2005 by McGraw Hill. This book will help teachers to understand the methodology and some practical hints in TEYL. The book is also completed by useful websites that teachers can browse to enrich their knowledge.

c. Teaching English to Children in Asia, David Paul, 2003 by Pearson Education North Asia Ltd. This will help teachers to understand better TEYL practice in Asian context. This book is completed by applicable activities and games.

d. Cambridge Advanced Learner's Dictionary Version 1,0. (2003). Cambridge University Press. This digital dictionary helps teacher to check the pronunciation of some words to avoid mispronunciation and misspelling.

e. A Handbook of Classroom English, Glyn S. Hughes, 1990 by Oxford University Press. This book is a collection of practical and valuable classroom English to enrich teachers' proficiency. It is undeniable that teacher talks play a very important role in pupil's language development. Teacher talks are also authentic language input for young learners, therefore teachers need to improve their classroomese.

f. www.teyl.com. This site provides teachers with resourceful journals and other publications which contain the current innovation and practices in teaching English to young learners. Teachers can also share their experiences and learn from other teacher's experiences in dealing with young learners.

2. Collection of communicative activities and teachers' resource materials The growing concern on TEYL is also a rich land for publishers and book writers. Therefore it is now very easy to get teachers resource books available everywhere. The series of collection of Resource Books for Teachers published by Oxford University Press is one very good example. The series range from collection of drama, gamës, -art projects, and stories. The books are also equipped by lesson plans which would be very useful for teachers in developing their activities. Here are samples from Andrew Wright's Storytelling with Children (2004): 


\subsection{Little Red Riding Hood}

Little Red Riding Hood's mother says, 'Little Red Riding Hood! Come here. Take this basket to your grandmother. There are sandwiches and there is a cake in the basket. Be carefull 'There is a wolf in the forest and he is very dangerous."

Litule Red Riding Hood walks in the forest. There are many big trees and beautiful flowers in the forest and the birds are singing. Iitule Red Riding Hood likes flowers and she picks them. She doesn't see the wolf hiding behind the tree. The wolf is thinking!

The wolf meets Little Red Riding Hood. He says, "Hello".

'Hello,' says Little Red Riding Hood.

"Where are you going?" asks the wolf.

'I'n going to my grandmother's cottage.'

'Oh! Where does she live?'

"She lives in a cottage in the forest."

'That's nice. OK. Goodbye. See you later.'

'Bye-bye!'

'Byre-bye!'

The wolf runs to Grandmother's cottage. He knocks on the door. 'Who's that?' says Grandmother.

'It's me!'

'Who's me?"

'It's Little Red Riding Hood!' says the wolf.

'Come in, dear!'

The wolf goes into the cottage and eats Grandmother. The wolf gets into bed. He waits for Little Red Riding Hood. He is hungry!

Little Red Riding Hood dances and sings in the forest. At last she comes to her grandmother's cottage.

She knocks on the door. 'Who's that?' says the wolf.

'It's me.'

"Who's me?"

'It's Isttle Red Riding Hood,' says Little Red Riding Hood.

"Come in, my dear."

Litrle Red Riding Hood goes into the cottage.

She looks at the wolf in bed. 'What big cars you've got,

Grandmother!'

"I want to hear you, my dear," says the wolf.

"What big eyes you've got, Grandmother!"

"I want to see yot, my dear."

"What big teeth you've got, Grandmother!"

'I want to eat you, my dear!"

The wolf jumps out of bed and eats Little Red Riding Hood.

A man comes. Fe has an axe. He kills the wolf. Grandmother and Little Red Riding Hood jump our of the wolf.

\section{Figure 3: Story script}




\section{Little Red Riding Hood: lesson plan 1}

LEVEL.

AGE

TIME

LANGUAGE

PREPARATION
Elementary and for those who have begun reading in their own language

8 to 12.

60 minutes

Lstening and reading flucncy: being able to skim through a text and get a general iden of its meaning

1 Photocopy the picture strip on the next page and the text of the story below. Make enough copies for one per group of four or five children. Remember you can photocopy directly on to card.

\begin{tabular}{|c|l|}
\hline \multicolumn{2}{|c|}{ LITILE RED RIDING HOOD } \\
\hline 1 & Take this basket to your grandmother. \\
\hline 2 & The wolf meets Little Red Riding Hood. \\
\hline 3 & The wolf runs to the Grandmother's cottage. \\
\hline 4 & The wolf gets into bed. \\
\hline 5 & Little Red Riding Hood comes to her Grandmother's cottage. \\
\hline 6 & She looks at the wolf kn bed. \\
\hline 7 & The wolf gumps cut of bed and eats Little Red Riding Hood \\
\hline 8 & A man comes and kills the wolf. \\
\hline
\end{tabular}

Photocopliable oxdord Untwersity Press

2 Glue the picture strip on to card and cut it up into separate pictures. Cut up the text and glue the relevant bits of the text onto the backs of the pictures. Remenber to cut off the sentence numbers!

3 Practise drawing the sketches in Step 1 (page 90).

\section{Figure 4: Lesson Plan}




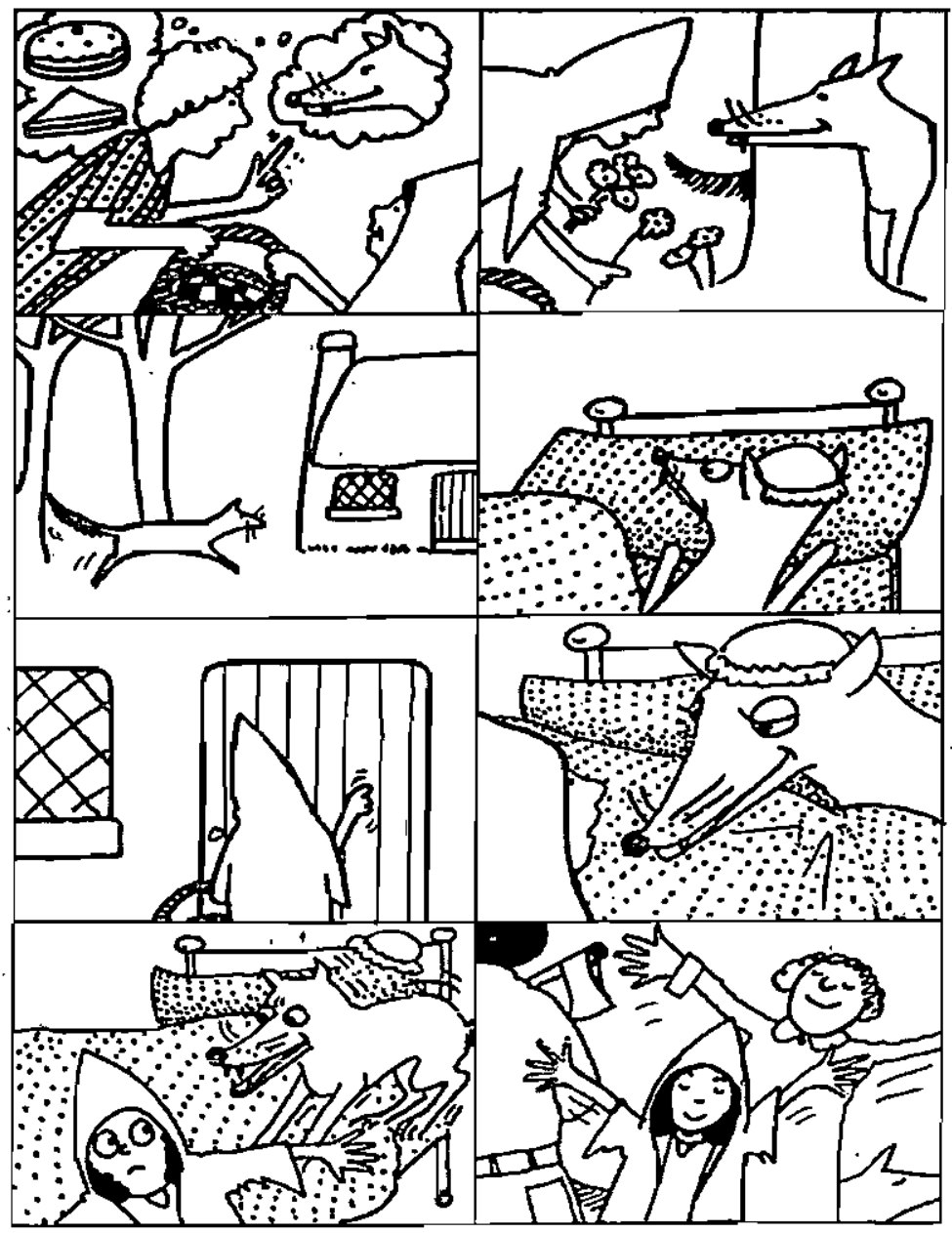

Phatocoplable ooxtod Utureasy press

Figure 5: Pictures for the story 
IN CLASS

\section{STORIES AND LESSON PLAN,}

1 Draw Litrle Red Riding Hood on the board. If you are not very good at drawing that is all the better! Here are some drawings to help you:
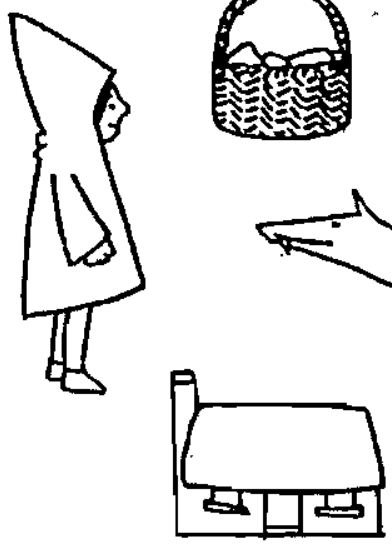
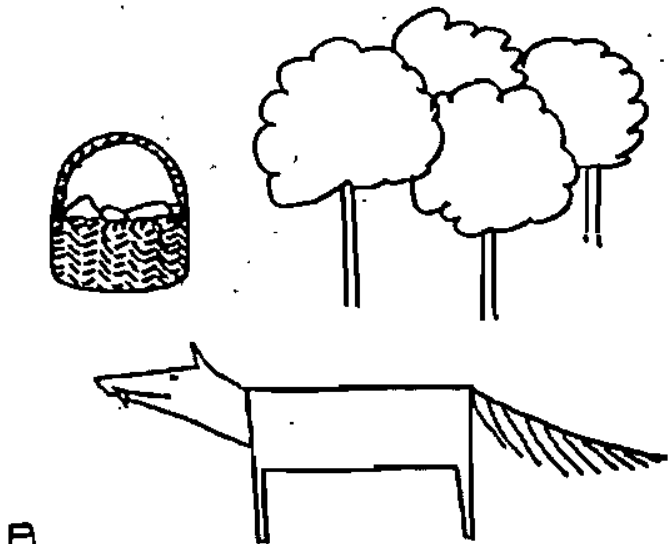

2 Ask:

You: Who's this?

Children: It's (L.jtle Red Riding Hood in mother tongue).

You: $\quad$ Yos, that's night. In English she's colled Little Red Riding Hood.

If they don't recognize her, you can draw the wolf, the forest, the little house, and the grandmother. Keep on asking who she/he/it is. Give the children the words wolf, forest, house, grandmother. If you want to explain the reason for Little Red Riding Hood's name in English, say that she has a kind of cloak (riding hood) which she wears all the time, so people call her after it. But point out that she doesn't ride a horse.

3 To find out if the children know the story, ask them to tell it to you as a class. A rudimentary relling is enough, for example: -Children: It's a gill. She goes to her grandnother. A twolf eats her grandmother. The wolf eas Lithis Red Riding Hood. A man comes. He kills the toolf.

4 Pur the children in groups of three to four, sitting around a table so that they can all see the pictures the right way up. Give each group a set of pictures.

\section{Figure 6: Class activity}


Another valuable resource is $1000+$ Pictures for Teachers to Copy by Andrew Wright published by Longman. This book provides teachers with photocopiable pictures and the practical clues on how to use those pictures. This book also gives practical instruction to help teachers to draw their own figures. One other interesting resource that teachers can use in the teaching is Function in English by Blundell et.al., 1992 published by Oxford University Press. This book is not designed as a material book for teaching young learners, rather it is designed for language learners who needs to know some English expressions used in different language functions. However, materials for teaching learning are everywhere out there as long teachers creatively adapt them. In using this book, then, teachers will need to select the simple expressions. Simple for the young learners would be the expressions which consist only $2-4$ words, easier to pronounce, and which are very much commonly used in daily language.

1. Authentic sources (newspaper or magazine articles, video, etc)

There are plenty of authentic materials in our environment. Teachers can cut pictures from magazines or newspapers and use them in their teaching practice. Shopping catalogues from several department stores or clothing outlets can also make a rich source of materials. VCDs and DVDs of animals wildlife from $\mathrm{BBC}$ or the National Geographic are available everywhere. Teachers can 'hunt' and select those materials most suitable for their needs.

2. Free downloaded materials from the internet.

The advancement of information technology like the internet allows. teachers to get more materials from the internet. Some free downloaded materials as mentioned earlier are here and there in the websites. Here are some of the free downloaded materials that teachers can use from the internet:

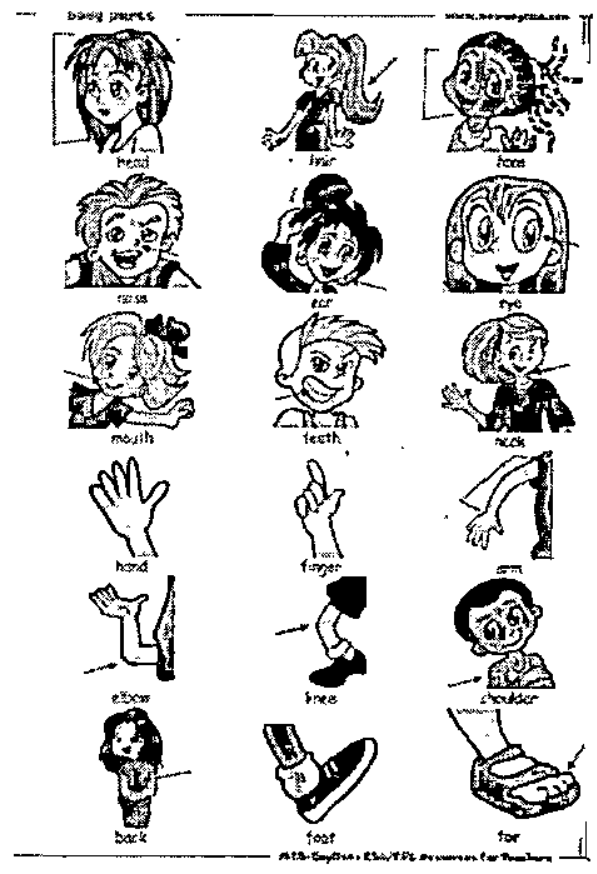


Test 3 Listening

Part 1

5 quetions.

Esten and drow Ifnes. There is gen exantole.
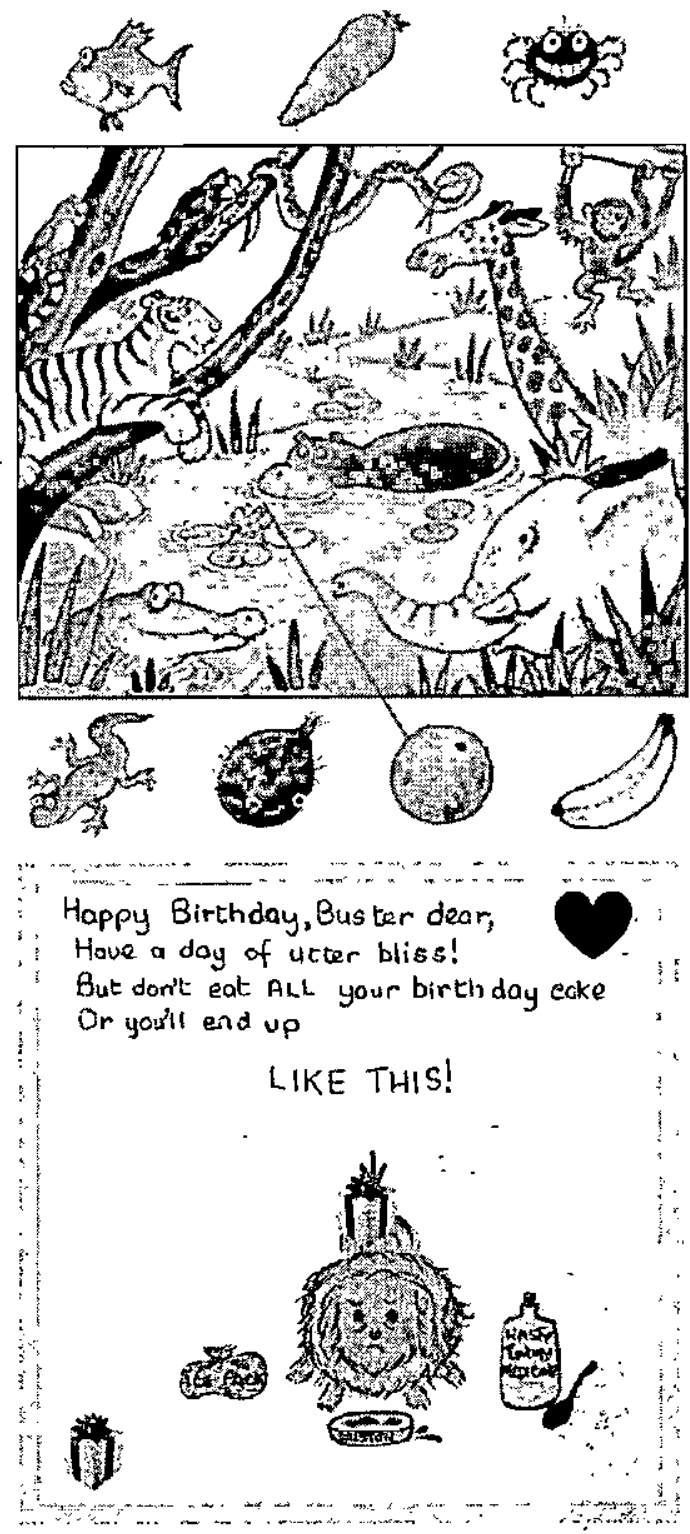

a. Pictures

Here is an example of a series of freely downloadable pictures:

Parts of the body. Retrieved December 4, 2009 from www.mes-english.com

b. Worksheet

There are invaluable sources of worksheet that teachers can use to enrich their collection. Teachers can directly use the worksheets in the classroom or adapt the worksheet to suit the students' level or age. Therefore these worksheets may also be the sources of inspiration when teachers plan to design the worksheets.

Cambridge Test. Retrieved November 28, 2008 from http://www.cambridge.org/el t

c. Samples of cards (invitation, birthday cards)

Internet provides thousands of examples of cards such as greeting cards, invitation cards, congratulating cards, thanking cards and many more. These cards can be 


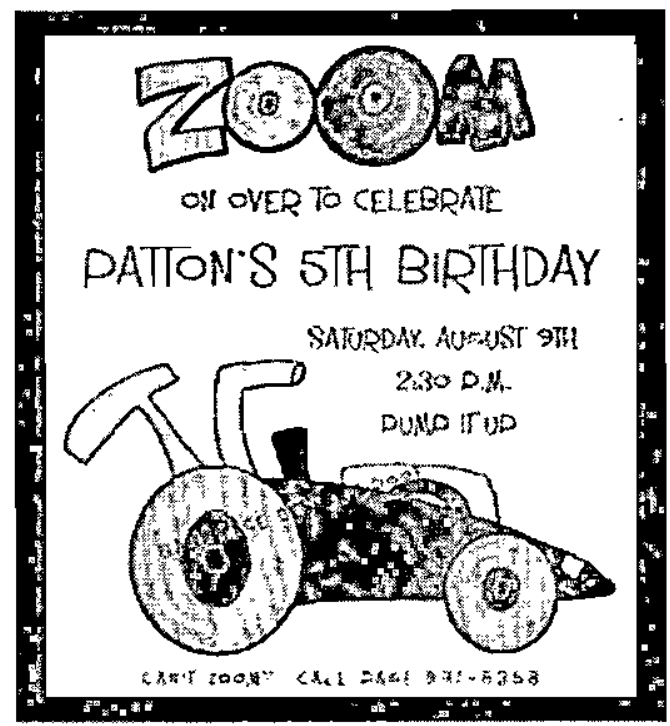

The weather

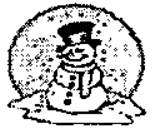

$m d n s f f \circ g g y g h$

$g c n s t d b s+t$ l k

b a y n m a b u c e ha

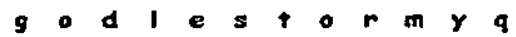

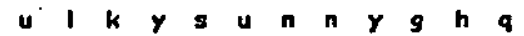

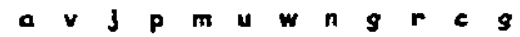

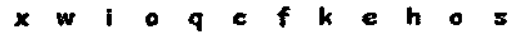

n $r \quad w \quad a \quad r \quad m \quad p \quad h \quad q \quad w \quad l \quad n$

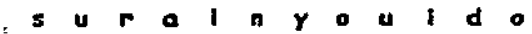

i $q$ I $c=a+1 n z w-$

- $v a v m z r h e d c y$

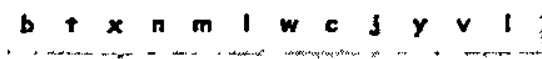

$$
\text { sunny rainy snowy }
$$

is cold hot windy stormy very valuable sources of learning reading and writing in English for children. These can also be examples of learning English through projects because designing cards involves students' creativity to draw, color, paint, cut and glue, and others.

d. Language (vocabulary) game Weather word search language game.

Retrieved December 4, 2009 from

\section{www.bogglesworldesl.com}

e. video and audio materials

Internet is also a great source of video and audio materials. Free-accessed video site like www.youtube.com provides a great number of videos that teachers can use in their teaching. Youtube provides easily -access short videos, kids songs, nursery rhymes, film trailers, short cartoon movies, or self-made and home-made videos that can become invaluable sources for an English classroom. 

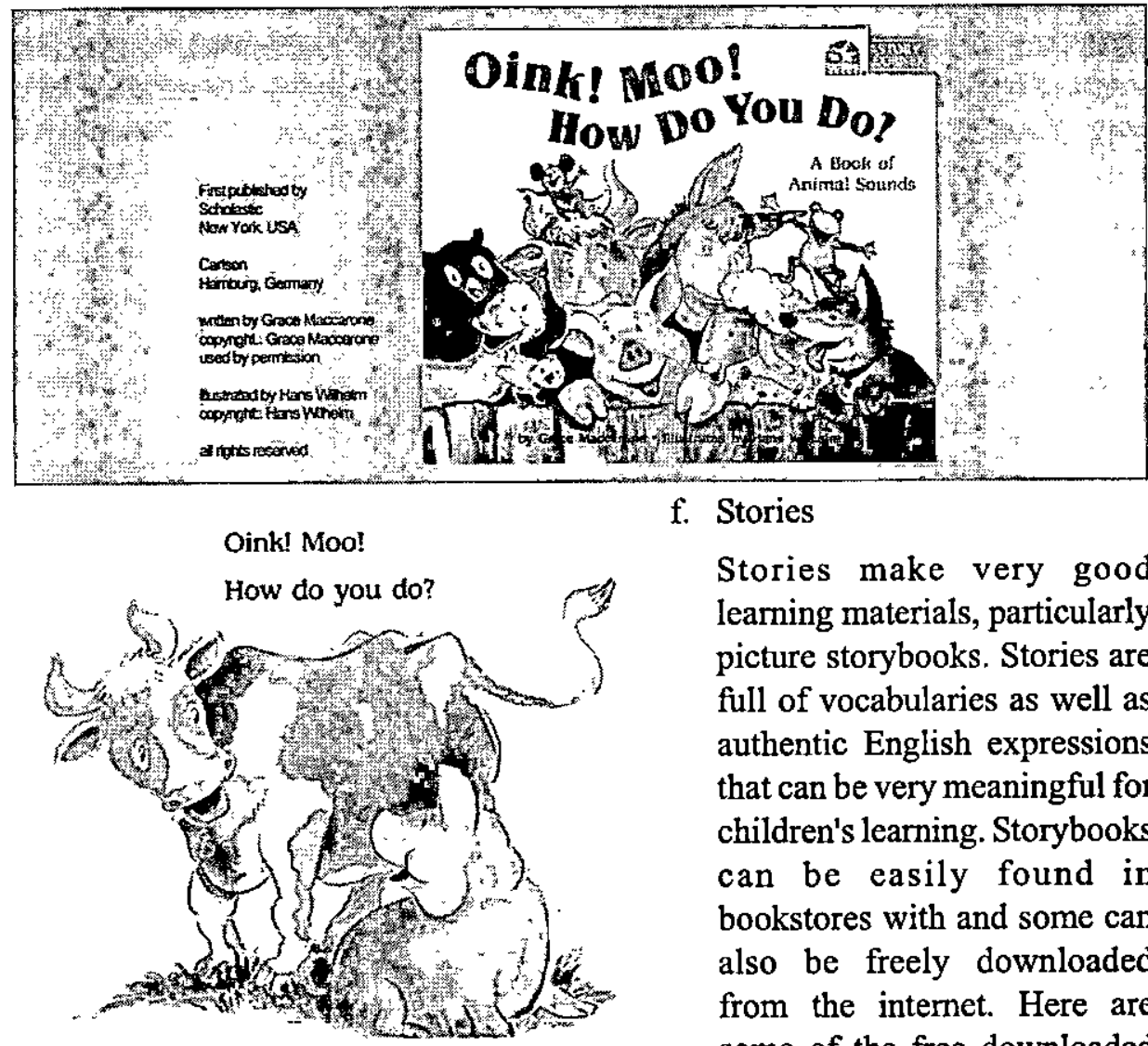

f. Stories

Stories make very good leaming materials, particularly picture storybooks. Stories are full of vocabularies as well as authentic English expressions that can be very meaningful for children's learning. Storybooks can be easily found in bookstores with and some can also be freely downloaded from the internet. Here are some of the free downloaded picture books:

\section{Oins! Moo! \\ How DO You Do?}

\section{A Book of Animal Sounds}

by Grace Maccarone

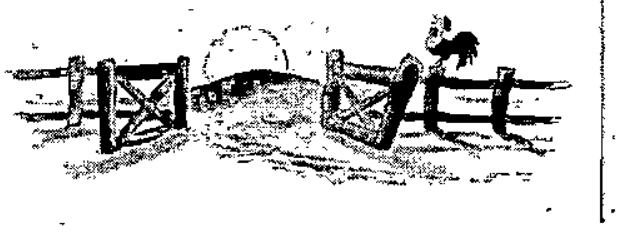
lllustrated by Hans Wijhelm 

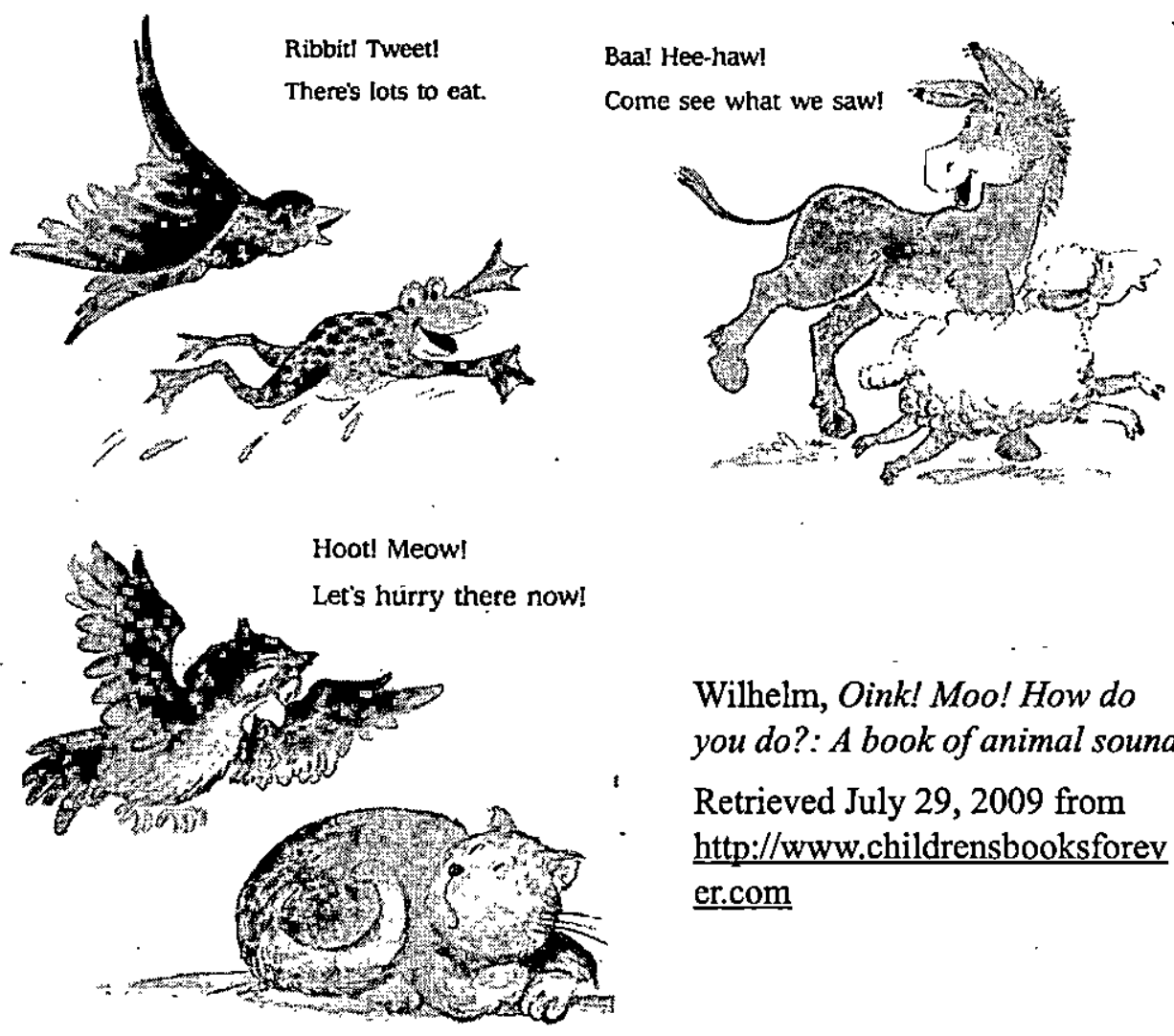

Wilhelm, Oink! Moo! How do you do?: A book of animal sound Retrieved July 29, 2009 from http://www.childrensbooksforev er.com

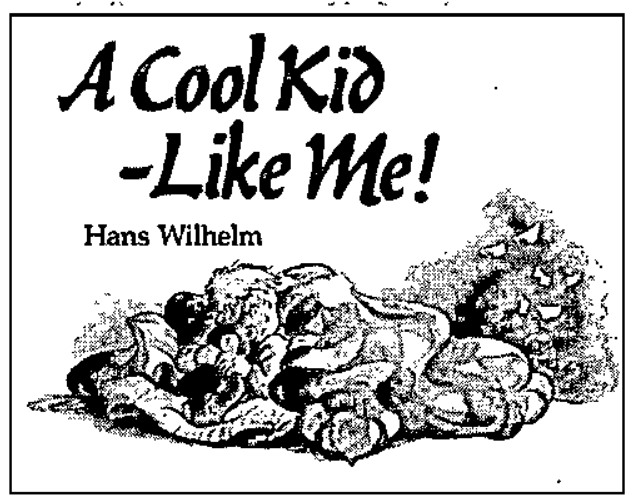

\section{ACool Kid -Like Me!}

Hans. Wilhelm

Crown Publishers, lne. New York

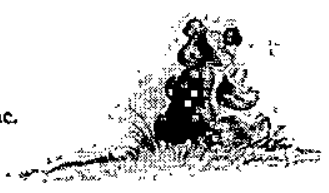


This story is about a kid everyone throught was so terifie and so conl. That kid wes me.
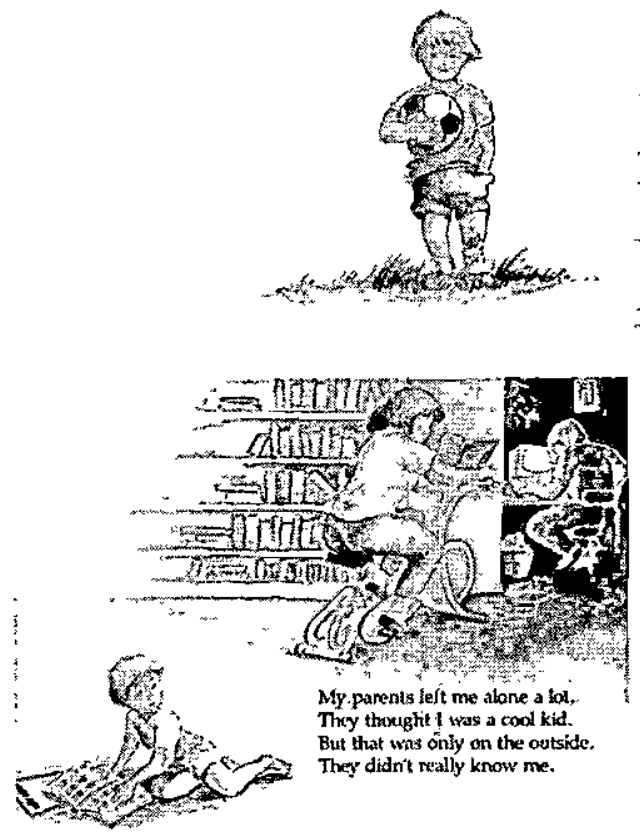

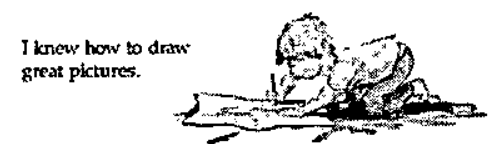

1 even brushed satr theth-
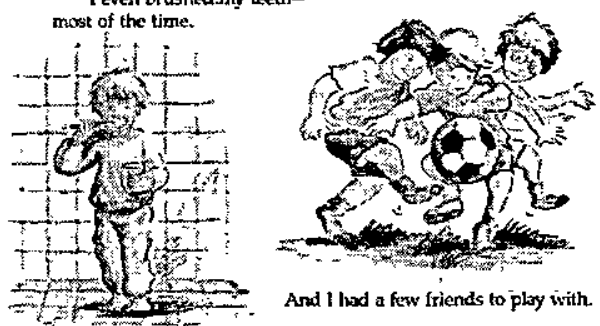

And I lasd a few friends to ploy with.

\section{Wilhelm, $A$ Cool Kid -Like Me}

Retrieved July 29, 2009 from http://www.childrensbooksforever.com

\section{Closing}

Learning materials for TEYL is everywhere. It can take the form of course book materials or supplementary materials. Sometimes, certain material cannot be fully exploited in teaching otherwise the teachers can manipulate them maximally to help the pupils in learning the target language. Therefore, it is not the material itself that should be enriched but also the teachers should be 'well-equipped' by appropriate and adequate teaching skills of the teaching English to Young Leamers. 


\section{REFERENCES}

Blundell, J. et al. (1992). Function in English. Oxford: Oxford University Press

Brewster, J. et.al. (2003). The primary English teacher's guide: Essex: Penguin Books Ltd.

Cambridge Advanced Learner's Dictionary Version 1,0. (2003). Cambridge University Press.

Hughes, G. S. (1990). A handbook of classroom English. Oxford: Oxford University Press

Kelly, G. (2000). How to teach pronunciation. Essex: Pearson Education Limited

Linse, C.T. (2005). Practical English language teaching: Young learners. New York: McGraw-Hill Companies Inc.

Moon, J. (2003). Children learn English. ........ McMillan-Heinemann English Language Teaching

Paul, D. (2003). Teaching English to children in Asia. Hong Kong: Pearson Education North Asia Ltd.

Spratt, M., et. al. (2005). The TKT (Teaching Knowledge Test) course. Cambridge: Cambridge University Press

Wright, A. (2004). Storytelling with children. Oxford: Oxford University Press

Wright, A. ( ).1000+ pictures for teachers to copy.........: Longman

\section{Online References}

http://www.bogglesworldesl.com

http:/www.cambridge.org/elt

http://www.childrensbooksforever.com -

http://www.mes-english.com

http://www.teachchildrenesl.com

http://www.teyl.com

http://www.youtube.com 